\title{
SACRED GEOGRAPHIES IN THE EURASIAN STEPPE: THE AQKOL SHRINE AS A SYMBOL OF KAZAKH ETHNICITY AND RELIGIOSITY*
}

I got the idea to study the Aqkol shrine while having tea with Birzhan, a friend of mine from the city of Ekibastuz, in Nazarbayev University canteen. It was the beginning of summer 2012 and I was a graduate student who had come to Kazakhstan to start preliminary fieldwork. I told my friend that I wanted to study representatives of a sacred lineage (qozha, in Kazakh), but I did not know how to start. Birzhan off-handedly told me he and his mother had visited a certain 'Qozha Ata' in a village - was it named 'Aqkol'? - in the early 1990s. To make conversation, I asked "is he still alive?", "who was he?", and "is there anything interesting there?" I thought that Birzhan had probably visited an obscure local healer who was already long dead. However, Birzhan told me that Qozha Ata was the descendent of a well-known saint, Ishan Ata, and that Qozha Ata's family maintained a shrine in the area. I could not have imagined that an Islamic shrine could have survived near a Sovietised industrial city such as Ekibastuz. The next weekend I joined Birzhan on a journey to Ekibastuz and started my study of the Aqkol shrine complex. I continued this fieldwork in the summers of 2012, 2013 and 2014, with an additional stay in 2018.

My main argument is that the Aqkol shrine complex reveals a strong relationship between religious and national identity as well as the development of civil religion (Coleman 1970) in contemporary Kazakhstan. In the years since independence, Muslim shrines have become perceived as part of the Kazakh national historical and cultural heritage; they are 'essential pillars' of the 'Kazakh national spirit' that provide ties to an imagined past. For example, the mausoleum of Akhmad Yasavi in Turkistan figures prominently in school textbooks and television programs; Yasavi is thus positioned as a 'Kazakh saint', whose shrine blesses the Kazakh state, rather than as a Muslim saint blessing Muslim land. There are also a number of smaller local shrines which are now highly praised by local elites and state institutions. A narrative in which ethnic identity, religion, and the nation-state are blended is growing around the shrines.

Since at least the late 19th century the Aqkol area has been home to Islamic sacred lineages. Qozhas are highly praised among Kazakhs, just as in other parts of the Muslim world and Central Asia (Basilov 1970; Demidov 1976; DeWeese 1999; Privratsky 2001). They are thought of as descendants of the Prophet Muhammad and his relatives. The local sacred lineage in Aqkol was founded by Murat Ishan, who came from the southern part of Kazakhstan. Later, Murat left Aqkol and returned with his two sons to the southern part of Kazakhstan, where he passed away. One of Murat's sons, Isabek, got a miraculous message via a dream (ayan in Kazakh), in which an unknown saint in a white robe asked him to return to Aqkol. Sacred prophetic dreams, or ayan, play and important role for Central Asian Muslims (Privratsky

* This research was undertaken within framework of project AP05135824, The Investment Potential of the Sacred Geography of Kazakhstan: Geospace Monitoring, IT Technology and Historical-Cultural Analysis in the Production of an Electronic Atlas of the Republic (2018-2020), funded by the Ministry of Education and Science of the Republic of Kazakhstan. 
2001 Louw 2010). Dreams of ancestral spirits (often elders in white cloth) are quite common among Kazakhs and widespread among Aqkol pilgrims and locals. Isabek returned to the Aqkol area, where he became a prominent saintly figure among the nomadic Arghyn tribes there (Frank 2013). The Arghyn tribes became the disciples (murid) of the Isabek lineage, just as other Kazakh communities had communal affiliations with other sacred lineages (DeWeese 2013). Terms of Sufi origin were widespread in these parts of the steppe region, for example duana (divona or dervish), ishan (pir or sheikh), piradar (barodar means 'brother' in Farsi, a term used for members of a Sufi brotherhood).

The tradition of pilgrimage to the graves of the Isabek lineage started after 1881 in Aqkol, after the building of a mausoleum devoted to Isabek Ishan. Later the area around Isabek's grave became a shrine complex devoted to the local Aqkol sacred lineage. Aqkol slowly became a place of shrine veneration and continued to function during the Soviet period, even during the Soviet antireligious campaigns. During the Soviet period, another Aqkol saint, a descendant of Isabek named Zhandarbek (1901-1996), continued the tradition of sainthood. He was known for small miracles, such as starting a dilapidated tractor and healing the sick. During the Soviet and early post-Soviet period, the shrines of Isabek Ishan and Zhandarbek were small mausoleums, built in the style of collective farmhouses. However, after the economic boom of the 2000s, the Aqkol shrine went through complete renovation thanks to the efforts of Pavlodar oblast officials and local elites. The reconstruction involved bringing new construction materials and architectural styles from western Kazakhstan, especially the Mangistau Peninsula. The majority of the donations for the reconstruction, amounting to more than 200,000 dollars, came from local individuals and businesses. The Aqkol shrines went from small Soviet-style buildings to tall Islamic domes. The shrine reconstruction ended with a large celebration of Isabek Ishan in the summer of 2011 (Bigozhin
2018), which cemented the shrine's new status. The shrine complex has become known on the regional and even national level.

The relationship between ethnicity and the sacred existed in Aqkol before the reconstruction, but was not as visible as it is today. For Aqkol Kazakhs and now for many pilgrims from other parts of the country (as far away as Almaty and the Russian Omsk), the steppe with mausoleums and ancestral graves was, and is, an imagined sacred homeland where saints and their tombs became associated and recognised by the local population as protectors of Kazakh religion. Being Muslim and being Kazakh are not separate things for many Kazakhs today and this characteristic often expresses itself in the veneration of ancestral spirits (aruakhs) and burials of ancestors, saints and saintly figures. Data collected during participant observation among pilgrims near Aqkol shrines show that for many Kazakhs pilgrimage to Aqkol was not only a religious act, but also a kind of hybrid in which religion, nationalism, a sense of belonging to Islam and even tourism all became interconnected and blended. For many pilgrims, especially those from urban centres, pilgrimage goes through space and time. It is a way to make contact with rural, 'traditional', life and to live for a couple of days in an imagined past, walking through the windy steppe to a shrine, sacrificing a sheep and cooking it on a wood stove, drinking fermented mare's milk, and more. The pilgrimage also becomes a symbolic return to tradition and 'the Steppe'. As Wendell Schwab (2012) has written, Kazakh tradition and history become Islamically authoritative for these types of pilgrim. For former Aqkol villagers (many Aqkol people left their village in the economically harsh period of the 1990s and 2000s and moved to more prosperous cities), a return to Aqkol also has a special symbolic meaning as a visit to the 'small Motherland', where they can touch the graves of their ishans and pirs.

State organisations have begun to frame Aqkol's shrines as part of national heritage. In 2017, as part of its 'Third Wave of Moderni- 
sation', Kazakhstan started a Spiritual Renovation program (Rukhani Zhanghyry); one of this program's goals is to build, or rebuild, the sacred past of the Kazakhs. This program encourages the classification and standardisation of sacred spaces in the form of edited volumes. The Kazakhstani government has a systematic approach to sacred spaces, places, and shrines, trying to find the exact number of these places and selecting a certain number of shrines, caves, mosques, temples, and churches for renovation. These often religious sacred objects are used to link Kazakhstan's diverse regions, religions, and ethnicities in a single national identity to form the patriotic modern citizen. In other words, Kazakhstan is developing its own civil religion using these shrines.

In the case of Aqkol, the close connection between religion and a national Kazakh identity is visible in the process of museumification of the shrine complex. Aqkol has its own small museum, located in the wing of the village's administrative building. In the museum, pictures of Zhandarbek or Isabek, or Zhandarbek's personal belongings are exposed and practically blended with an official vision of the Kazakhstani history, thus creating a sense of belonging to Aqkol within an official discourse on the Kazakhstani past and present. The state-run mass media slowly built up public interest in the Aqkol's renovated shrines, leading to the construction of a nationalistic narrative around Aqkol. From being local Kazakh tribal saints, Isabek and Zhandarbek slowly joined the pantheon of all-Kazakh saints.

Ulan Bigozhin (Nazarbayev University)

\section{References}

Basilov, Vladimir. 1970. Kul't svyatykh v islame. Moskva: Izdatel'stvo Mysl'. [Басилов, Владимир. 1970. Культ святых в исламе. Москва: Издательство Мысль.]

Bigozhin, Ulan. 2018. 'Nation-Building and a School Play in a Kazakh Saint's Jubilee', Central Asian Affairs 5 (1): 16-31. DOI: https://doi. org/10.1163/22142290-00501002.

Coleman, John A. 1970. Civil Religion. - Sociological Analysis 2 (31): 67-77. DOI: https://doi. org/10.2307/3710057.

Demidov, Sergey. 1976. Turkmenskiye ovlyady. Ashkhabad: Izdatel'stvo Ylym. [Демидов, Сергей. 1976. Туркменские овлядь. Ашхабад: Издательство Ылым.]

DeWeese, Devin. 1999. The Politics of Sacred Lineages in 19th-Century Central Asia: Descent Groups Linked to Khwaja Ahmad Yasavi in Shrine Documents and Genealogical Charters. - International Journal of Middle East Studies 31 (4): 507-530. DOI: https://doi.org/10.1017/ S002074380005707X.

DeWeese, Devin. 2013. The Yasavī Presence in the Dasht-i Qipchaq from the 16th to 18th Century. - Islam, Society and States across the Qazaq Steppe (18th - Early 20th Centuries), edited by Niccolò Pianciola and Paolo Sartori. Wien: Austrian Academy of Sciences Press, 27-68. DOI: https:// doi.org/10.2307/j.ctt1vw0r3p.5.

Frank, Allen J. 2013. Sufis, Scholars, and Divanas of the Qazaq Middle Horde in the Works of Mäshhür Zhüsip Köpeyulï. - Islam, Society and States across the Qazaq Steppe (18th - Early 20th Centuries), edited by Niccolò Pianciola and Paolo Sartori. Wien: Austrian Academy of Sciences Press, 213-232. DOI: https://doi.org/10.2307/j. ctt1vw0r3p.11.

Louw, Maria E. 2010. Dreaming up Futures. Dream Omens and Magic in Bishkek. - History and Anthropology 21 (3): 277-292. DOI: https://doi. org/10.1080/02757206.2010.496780.

Privratsky, Bruce. 2001. Muslim Turkistan. Richmond, VA: Curzon.

Schwab, Wendell. 2012. Traditions and Texts: How Two Young Women Learned to Interpret the Qur'an and Hadiths in Kazakhstan. - Contemporary Islam 6 (2): 173-197. DOI: https://doi. org/10.1007/s11562-011-0177-4. 